\title{
Seed Predation, Seedling Emergence, and Rhizome Characteristics of American Licorice
}

\author{
A. BOE AND R. WYNIA
}

\begin{abstract}
American licorice (Glycyrrhiza lepidota Pursh) is a widespread native legume that may have potential forage or soil conservation uses. Seed predation, seedling emergence, and rhizome production were studied in 41 populations of $G$. lepidota from North and South Dakota. Seed predation by the beetle Acanthoscelides fraterculus (Horn) reduced viable seed production by 7 to $71 \%$. Seedling emergence in the greenhouse and stand establishment in the field varied considerably among populations. Overall mean field emergence was $41 \%$. Five South Dakota populations exhibited lethal chlorophyll deficient seedlings. Rhizome numbers of yearold spaced-plants ranged from 3 to 32 , with a mean of 13.3. Mean number of nodes/rhizome was 7.5. This study indicated that stands of $G$. lepidota could be established from seed and individual plants could spread rapidly by rhizomes. However, heavy seed predation by bruchid beetles and lack of inflorescence production in cultivated nurseries could seriously limit viable seed production.
\end{abstract}

American licorice (Glycyrrhiza lepidota Pursh) is a native perennial legume common to disturbed areas, draws, woods, and depressions in prairies over much of temperate North America (Duke 1981). It is utilized by livestock in the Great Plains (Weaver 1954, Johnson and Nichols 1982) and produces highly digestible forage (Fransen and Boe 1981). It has been recognized for its soil binding capabilities (Allen and Allen 1981, Duke 1981), has a wide ecologic amplitude (Duke 1981), and has exhibited vigorous growth on mine spoil material at Dickinson, N. Dak. (Whitman 1979). Janzen (1969) reported that seed beetles prey on numerous wild and cultivated legumes and Baker (1895) observed heavy infestations by Acanthoscelides fraterculus (Horn) on G. lepidota near Ft. Collins, Colo.

Native legumes offer tremendous potential for enhancing the productivity of pastures and rangelands where introduced species are not adapted or desired (Davis 1982). Williams and Davis (1982) identified several Astragalus species free from toxic components and suggested they were a reservoir from which useful cultivars could be developed. The widespread occurrence of G. lepidota in North America suggests genetic variability within that species for seed production, stand establishment, forage production, and soil conservation characteristics. Before any native legume can be accurately evaluated for cultivated forage or soil conservation purposes, efficient methods of propagation must be identified. Studies on sexual and vegetative reproduction characteristics of native legumes should provide critical information for those interested in propagating selected populations for potential cultivar development. Our objectives were to evaluate populations of $G$. lepidota from the Dakotas for: (1) seed predation by seed beetles, (2) seedling emergence, and (3) rhizome production.

\section{Materials and Methods}

Bulk pod collections were obtained from 41 different populations in North and South Dakota in April 1980 or August 1981

\footnotetext{
Authors are assistant professor and research assistant. Plant Science Department. South Dakota State Univ., Brookings 57007.

This article is a contribution from the South Dakota State Univ. Agr. Exp. Sta., Brookings 57007. Journal Paper No. 1971.

The authors wish to gratefully acknowledge the assistance of Dr. B. McDaniel, who provided identification of Acanthoscelides fraterculus (Horn).

Manuscript accepted November 5, 1984.
}

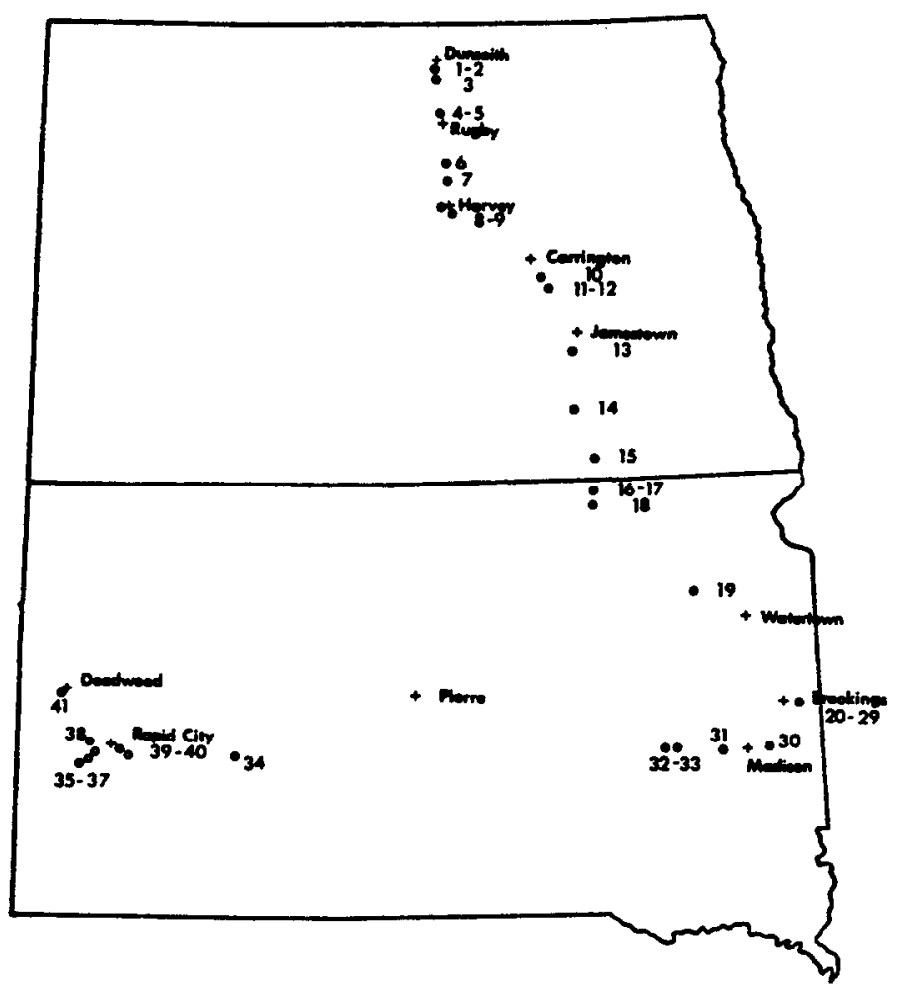

Fig. 1. Approximate geographical location of 41 populations of Glycyrrhiza lepidota collected in North and South Dakota in 1980 or 1981.

(Fig. 1). Populations in North Dakota were all within $100 \mathrm{~m}$ of U.S. Hwys 52 or 281 . South Dakota populations were not necessarily limited to areas easily accessible from a major road way. Pods were carefully threshed in bulk on a rubber threshing board. Two random 50-seed samples from the bulk pod collections of each of 37 populations were examined for presence of immature seed beetles. This was done by pressing the point of a dissecting needle against the pericarp. Pericarps of seeds containing beetles were easily punctured. Five random 50 -uninfested-seed samples were obtained from each of 18 South Dakota populations for determination of seed weights.

In November 1983, 200 random pods saved for individual pod analysis from population 20 were examined for the following: (1) total number of seeds, (2) number of beetle-destroyed seeds, and (3) number of noninfested seeds. The pods had been stored at room temperature in heavy paper envelopes since collection and adult beetles had emerged prior to examination.

In July 1980, 150 2-month old seedlings ( 15 plants from each of 10 South Dakota populations) were transplanted from the greenhouse to a spaced-plant nursery at Brookings, S. Dak. Interplant spacing was $100 \mathrm{~cm}$. In July 1981,23 plants representing 9 populations were excavated and the following data were obtained for each: (1) rhizomes/plant, (2) rhizome lengths, (3) branches/rhizome, and (4) nodes/rhizome. 
In November 1981, 11 populations were planted in the greenhouse in a 20-replicatc randomized complete block design. In each replication, 5 seeds / population were planted in $5.0-\mathrm{cm}$ peat pots at a depth of $1.3 \mathrm{~cm}$ in a steam-sterilized $3: 1$ soil:sand mixture. Emergence was noted at 14 days after planting. Seedling abnormalities and mortality were observed through 30 days after planting.

In June 1982, 22 populations were planted in the field at Brookings in a 3-replicate randomized complete block design. In each replicate, 50 seeds/population were pianted equidistant at a depth of $2.5 \mathrm{~cm}$ in a $0.9 \mathrm{~m}$ row. Interrow spacing was $0.9 \mathrm{~m}$. Seedling emergence and abnormality data were collected 14 days after planting. In September 1982, vigor notes (scale was from $7=$ most vigorous (full stand, lateral shoots from rhizomes) to $1=$ least vigorous (less than 5 shoots, no lateral spread)) were taken for each row.

All sceds used in greenhouse and field plantings were scarified for 15 seconds in a Forsberg laboratory scarifier just prior to planting. Previous germination studies had indicated a high percentage of hard seeds for this species (Boe and Wynia, unpublished data, Plant Science Department, SDSU).

\section{Results and Discussion}

\section{Seed Predation}

In the study of bulk pod collections from 37 populations, immature bruchid beetles, identified as Acanthoscelides fraterculus (Horn), were found in every population. The highest $(71 \pm 7 \%)$ and lowest $(7 \pm 5 \%)$ mean infestations were found in collections from Fsmond, N. Dak. (population 7), and Brookings, S. Dak. (population 28 ) in 1980, respectively. The overall mean infestation of 74 50 -seed samples was $41 \pm 2 \%$. These data indicate that seed beetles have the capacity to drastically reduce viable seed production in $G$. lepidota over a wide geographic area in the Northern Great Plains and concur with observations made by Baker (1895) in Colorado.

In the analysis of individual pods from population 20 , a total of 480 seeds $(\bar{x}=2.4$ seeds $/$ pod) was obtained from a 200 -pod sample. Thirty percent of the seeds from population 20 were beetledestroyed (pericarp with emergence hole was all that remained); 48\% appeared normal (pericarp was hard, glossy, and intact); and $22 \%$ wer abnormal (pericarp was dull and easily crushed to expose discolored and diminutive cotyledons). Forty pods contained 2 or 3 beetle-destroyed seeds, 57 pods contained 1 beetle-destroyed seed, and 103 pods contained no beetle-destroyed seeds. Rogers and Garrison (1975) found considerable seed destruction by Acanthoscelides collusus (Fall) in seed pods of Amorphafruticosa $\mathrm{L}$.. in Texas. Johnson (1981) pointed out that seeds from legumes with indehiscent pods retained on the stem were more susceptible to seed beetle (family Bruchidae) predation than those from dehiscent pods. Pods of $G$. lepidota are indehiscent and remain on the woody stems long after seed maturity. We have observed mature pods in the spring still attached to culms produced the previous growing season.

\section{Seed Weight}

Mean 50-seed weights from 18 South Dakota populations ranged from $300 \pm 14$ to $470 \pm 10 \mathrm{mg}$. Janzen (1969) pointed out that bruchid beetles feed on the seeds of a large majority of legume species with medium-sized hard seeds. Center and Johnson (1974) reported that many wild herbaceous legumes produce seeds too small for bruchids to complete their life cycle; however some bruchid species circumvent this problem by feeding on several seeds. The correlation coefficient between mean 50 -seed weight and percent infestation was not significant, indicating that smaller seed within $G$. lepidota did not deter damage from seed beetle predation.

\section{Rhizome Characteristics}

Rhizome characteristics of 23 spaced-plants from 9 populations are presented in Table 1. Rhizome number ranged from 32 to 3 for individual plants from populations 22 and 24 , respectively. The
Table 1. Means for rhizome characteristics of 23 spaced-plants from nine different populations one year after establishment in a field nursery at Brookings, SD.

\begin{tabular}{|c|c|c|c|c|c|}
\hline $\begin{array}{l}\text { Popu- } \\
\text { lation }\end{array}$ & $\begin{array}{c}\text { Number } \\
\text { of } \\
\text { plants }\end{array}$ & $\begin{array}{l}\text { Rhizome } \\
\text { number }\end{array}$ & $\frac{\text { Branches }}{\text { rhizome }}$ & $\frac{\text { Nodes }}{\text { rhizome }}$ & $\begin{array}{l}\text { Rhizome } \\
\text { length } \\
\mathrm{cm}\end{array}$ \\
\hline 21 & 3 & $4.7 \pm 0.3^{\prime}$ & $1.9 \pm 0.71$ & $13.1 \pm 1.51$ & $59.0 \pm 7.81$ \\
\hline 22 & 3 & $20.0 \pm 6.9$ & $1.5 \pm 0.4$ & $9.0 \pm 0.6$ & $43.0 \pm 3.0$ \\
\hline 24 & 3 & $9.7 \pm 3.5$ & $0.2 \pm 0.2$ & $9.8 \pm 0.8$ & $35.3 \pm 3.0$ \\
\hline 25 & 2 & $16.0 \pm 4.0$ & $0.8 \pm 0.3$ & $12.0 \pm 1.1$ & $45.0 \pm 4.8$ \\
\hline 27 & 2 & $14.5 \pm 4.5$ & $1.3 \pm 0.5$ & $13.6 \pm 1.3$ & $48.3 \pm 4.8$ \\
\hline 31 & 2 & $12.5 \pm 4.5$ & $1.4 \pm 0.6$ & $7.6 \pm 1.1$ & $42.5 \pm 6.5$ \\
\hline 39 & 3 & $21.0 \pm 3.8$ & $1.1 \pm 0.3$ & $9.0 \pm 0.5$ & $43.5 \pm 2.8$ \\
\hline 40 & 2 & $8.5 \pm 1.5$ & $1.2 \pm 0.5$ & $12.4 \pm 1.3$ & $47.3 \pm 5.8$ \\
\hline 41 & 3 & $12.0 \pm 5.7$ & $1.3 \pm 0.5$ & $11.3 \pm 0.7$ & $42.8 \pm 3.0$ \\
\hline
\end{tabular}

'Standard error of mean.

longest rhizome $(162.5 \mathrm{~cm})$ was obtained from a plant from population 31. Most rhizomes had only 1 or 2 branches, but averaged greater than 7.5 nodes. In July 1982, it was no longer possible to identify individual spaced-plants in the nursery, as extensive shoot production had occurred from nodes on rhizomes that had spread into interplant spaces. These data indicate that G. lepidota ecotypes from South Dakota have tr mendous vegetative reproduction potential and add quantification to observations of Allen and Allen (1981) and Duke (1981) regarding its soil-binding capabilities. Whitman (1979) reported that $G$. lepidota showed exceptionally vigorous growth on mine spoil material at Dickinson, N. Dak., and was one of the best native forbs he evaluated for providing dense cover on that substratc. Since it is a legume, G. lepidota may have potential for utilization as a stabilizer of disturbed soils, particularly those that are low in available nitrogen.

\section{Seedling Emergence}

Considerable variation was found among populations for greenhouse and field emergence (Table 2). Percent emergence in

Table 2. Mean percent emergence, percent chlorophyll deficient seedlings, and vigor ratings in greenhouse and field studies of $\boldsymbol{G}$. lepidota.

\begin{tabular}{|c|c|c|c|c|c|}
\hline \multirow[b]{2}{*}{$\begin{array}{l}\text { Popu- } \\
\text { lation }\end{array}$} & \multicolumn{2}{|c|}{ Greenhouse } & \multicolumn{3}{|c|}{ Field } \\
\hline & Emergence & $\begin{array}{c}\text { Chlorophyll } \\
\text { deficient } \\
\text { seedlings }\end{array}$ & Emergence & $\begin{array}{c}\text { Chlorophyll } \\
\text { deficient } \\
\text { seedlings }\end{array}$ & Vigor \\
\hline & & & $\%$ & & \\
\hline 11 & & & $57 \pm 1.8^{1}$ & 0 & $2.3 \pm 0.3^{\mathrm{I}}$ \\
\hline 13 & & & $64 \pm 9.9$ & 0 & $4.3 \pm 0.3$ \\
\hline 15 & & & $58 \pm 9.5$ & 0 & $5.3 \pm 0.7$ \\
\hline 19 & & & $71 \pm 5.9$ & 0 & $4.3 \pm 0.3$ \\
\hline 20 & $47 \pm 4.41$ & 0 & $20 \pm 14.6$ & 0 & $2.7 \pm 1.2$ \\
\hline 21 & $7 \pm 2.7$ & 0 & $19 \pm 10.6$ & 0 & $2.7 \pm 1.2$ \\
\hline 22 & $97 \pm 1.6$ & 4 & $71 \pm 21.5$ & 10 & $3.3 \pm 0.9$ \\
\hline 23 & & & $4 \pm 2.0$ & 0 & $1.7 \pm 0.3$ \\
\hline 24 & & & $34 \pm 20.3$ & 0 & $2.7 \pm 1.2$ \\
\hline 25 & & & $26 \pm 3.1$ & 5 & $2.7 \pm 0.3$ \\
\hline 26 & & & $7 \pm 1.8$ & 0 & $1.3 \pm 0.3$ \\
\hline 27 & $45 \pm 4.9$ & $\mathbf{0}$ & $48 \pm 10.3$ & 0 & $3.0 \pm 0.6$ \\
\hline 28 & & & $73 \pm 10.4$ & 0 & $5.7 \pm 0.9$ \\
\hline 29 & & & $65 \pm 3.7$ & 0 & $6.7 \pm 0.3$ \\
\hline 30 & $71 \pm 4.1$ & 0 & $60 \pm 6.9$ & 0 & $4.3 \pm 0.3$ \\
\hline 31 & $82 \pm 5.3$ & 0 & $42 \pm 19.0$ & 0 & $4.3 \pm 1.5$ \\
\hline 33 & $81 \pm 8.5$ & 0 & $55 \pm 14.4$ & 0 & $2.7 \pm 0.3$ \\
\hline 35 & & & $16 \pm 9.2$ & 4 & $2.3 \pm 0.9$ \\
\hline 36 & $14 \pm 4.8$ & 0 & $11 \pm 9.4$ & 0 & $1.7 \pm 0.3$ \\
\hline 38 & 0 & 0 & 0 & 0 & - \\
\hline 39 & $60 \pm 8.2$ & 2 & $37 \pm 4.4$ & 0 & $4.0 \pm 0.6$ \\
\hline 41 & $79 \pm 4.2$ & 14 & $53 \pm 26.7$ & 18 & $4.0 \pm 1.5$ \\
\hline
\end{tabular}

'Standard error of mean. 
the greenhouse range from 0 to $97 \%$, while field emergence ranged from 0 to $73 \%$ with an overall mean of $41 \%$. The linear correlation coefficient between greenhouse and field emergence was 0.90 $(P<0.01)$. Whitman (1979) found the germinability of fieldcollected $G$. lepidota seeds to be among the highest of 30 native forb species from North Dakota, but he also noted that germination varied considerably between years of seed collection. Populations 22 and 41 exhibited rapid and uniform germination and field emergence after scarification, but produced chlorophyll deficient seedlings (cotyledons were pale yellow to nearly white) in both greenhouse and field plantings. Population 41 exhibited 14 and $18 \%$ chlorophyll deficient seedlings in greenhouse and field plantings, respectively, and $26 \%$ seedling mortality in steam-sterilized soil in the greenhouse. Seedlings with chlorotic cotyledons did not produce leaves above the cotyledons and were generally dead within 10 days after emergence. Total chlorophyll (chlorophyll a and $b$ ) of the deficient seedlings from population 41 were reported earlier (Wynia et al. 1981), and were highly significantly $(P<0.01)$ less than those of normal seedlings from the same population. Seedling mortality due to chlorophyll deficiency appears to have, along with seed beetle predation, the potential to limit the number of individuals produced from sexual reproduction in native populations.

Vigor ratings of $0.9 \mathrm{~m}$ rows approximately 1 year after planting ranged from 1.3 to 6.7 (Table 2), indicating that stands could be successfully established from seed collection from native populations. Several populations produced culms taller than $75 \mathrm{~cm}$, but very few seed pods were set in 1982 . Whitman (1979) reported that $G$. lepidota plants established by seeding and transplanting on mine spoil material at Dickinson, N. Dak., did not flower over a 2 -year observation period. Individual rows of the most aggressive populations $(15,28$, and 29$)$ were hard to distinguish in 1982 , as numerous shoots had been produced from rhizomes that had spread into interrow spacings. Several researchers (Abrahamson 1975, Holler and Abrahamson 1977, Williams 1975) have indicated that vegetative reproduction should be favored as a means of low risk, local spread when intraspecific or interspecific competition is low. When population density becomes high, sexual reproduction should be favored as a means of dispersal to new, more favorable environments. Since our nurseries and field plots were kept free of other plant species, the tremendous vegetation reproduction and paucity of sexual reproductive structures we observed may represent allocation of reproductive resources to opportunistic utilization of immediate microhabitats.

\section{Conclusions}

Data obtained from this study may prove useful to researchers involved in the initial germplasm collection and propagation of native legumes which have potential for domesticated forage, soil conservation, or other uses. Although small field plots of several $G$. lepidota ecotypes were easily established from seed collected in nature, seed predation by $A$. fraterculus and sparse inflorescence production in cultivated nurseries would have to be overcome before reliable seed supplies could be obtained for forage or soil conservation evaluation plantings. Glycyrrhiza glabra L., the source of licorice extract, is propagated commercially by rhizome and crown pieces because establishment from seed is difficult. Since $G$. lepidota also produces abundant rhizomes, this method may offer an alternative to establishing evaluation plots from seed.

\section{Literature Cited}

Abrahamson, W.G. 1975. Reproductive strategies in dewberries. Ecology 56:721-726.

Allen, O.N., and E.K. Allen. 1981. The Leguminosae: A source book of characteristics, uses, and nodulation. University of Wisconsin Press.

Baker, C.F. 1895. Biological notes on some Colorado Coleoptera. Ent. News 6:27-28.

Center, T.D., and C.D. Johnson. 1974. Coevolution of some seed beetles (Coleoptera: Bruchidae) and their hosts. Ecology 55:1096-1103.

Davis, A.M. 1982. Crude protein, crude fiber, tannin, and oxalate concentrations of 38 Astragalus species. J. Range Manage. 35:32-34.

Duke, J.A. 1981. Handbook of legumes of world economic importance. Plenum Press. N.Y.

Fransen, S.C., and A. Boe. 1981. Laboratory quality determinations of American licorice (Glycyrrhiza lepidota Push). Proc. S.D. Acad. Sci. 60:171.

Holler, L.C., and W.G. Abrahamson. 1977. Seed and vegetative reproduction in relation to density in Fragaria virginiana (Rosaceae). Amer. J. Bot. 64: 1003-1007.

Janzen, D.H. 1969. Seed-eaters versus seed size, number, toxicity, and dispersal. Evolution. 23:1-27.

Johnson, C.D. 1981. Interactions between Bruchid (Coleoptera) feeding guilds and behavioral patterns of pods of the Leguminosae. Env. Ent. 10:249-253.

Johnson, J.R., and J.T. Nichols. 1982. Plants of South Dakota grasslands. S.D. Agr. Exp. Sta. Bull. 566.

Rogers, C.E., and J.C. Garrison. 1975. Seed destruction in Indigobush Amorpha by a seed beetle. J. Range Manage. 28:241-242.

Weaver, J.E. 1954. North American Prairie. Johnsen, Lincoln, Neb.

Whitman, W.C. 1979. Selection and increase of perennial forbs for mine spoil reclamation in the Northern Great Plains. Final report on cooperative project between N. Dak. Agr. Exp. Sta. and U.S. Forest Service.

Williams, G.C. 1975. Sex and evolution. Princeton University Press, Princeton, N.J.

Williams, M.C., and A.M. Davis. 1982. Nitro compounds in introduced Astragalus species. J. Range Manage. 35:113-115.

Wynia, R., A. Boe, and W. Gardner. 1981. Initial investigation of chlorophyll deficient cotyledons of American Licorice (Glycyrrhiza lepidota Pursh). Proc. S.D. Acad. Sci, 60:173. 